\title{
Prospective measurement of glomerular filtration rate and effective renal plasma flow during treatment of malignant essential hypertension
}

\author{
R. R. GHOSE \\ F.R.C.P. \\ Singleton Hospital, Sketty, Swansea SA2 8QA
}

\begin{abstract}
Summary
A longitudinal study of sequential measurement of glomerular filtration rate and effective renal plasma flow was conducted over a 5-year period of antihypertensive drug treatment, in four adult patients admitted to hospital with previously untreated malignant essential hypertension. Treatment produced a substantial and sustained lowering of systemic arterial blood pressure, compared with grossly elevated pretreatment levels. Nevertheless, glomerular filtration rate and effective renal plasma flow remained relatively stable in all four patients, at roughly the same level at which they were admitted. It was concluded that effective therapy for hypertension may not necessarily reverse the vascular changes of arteriolar fibrinoid necrosis, which characterize malignant essential hypertension. Permanent damage to the renal arterioles, and the territory of kidney supplied by these vessels, may be a feature of this condition.
\end{abstract}

KEY WORDS: glomerular filtration rate, effective renal plasma flow, malignant essential hypertension.

\section{Introduction}

There are few prospective studies of renal function in patients who present with malignant essential hypertension (MHT). In a long-term study of 24 patients with MHT it was apparent that the extent of initial renal damage, and the quality of blood pressure (BP) control, were of paramount importance. In 17 patients with initial mean serum creatinine concentration of $169 \pm 19 \mu \mathrm{mol} / 1$, glomerular filtration rate (GFR) increased from $51 \pm 7$ to $62 \pm 6$ $\mathrm{ml} / \mathrm{min}$. BP control was satisfactory in this group, whereas in seven patients, with initial mean serum creatinine concentrations of $448 \pm 105 \mu \mathrm{mol} / 1$, there was rapid deterioration into end-stage renal failure and BP control was poor (Herlitz, Gudbransson and Hansson, 1982). The present study assesses the degree of recovery of GFR and effective renal plasma flow (ERPF) in a small group of patients with untreated
MHT, who presented with normal or slightly raised serum creatinine concentration, and who were treated aggressively for hypertension from the time of admission.

\section{Patients and methods}

Four patients, emergency admissions to hospital on account of headaches (cases 1 and 2), and visual impairment (cases 3 and 4), were found to have untreated MHT with systolic blood pressure (SBP) of $220 \mathrm{mmHg}$ or more, and diastolic blood pressure (DBP) of $140 \mathrm{mmHg}$ or more. Hypertensive retinopa thy (Grade IV-Keith-Wagener classification) w present in all patients. Anti-hypertensive drug treatment was commenced immediately, and good BP control was achieved within 1 week. Secondary hypertension was excluded by the following laboratory tests: (i) intravenous urography; (ii) gamma $\underset{F}{\Rightarrow}$ camera renography using technetium-99m DTPA; (iii) serum electrolyte concentrations; (iv) urinary catecholamine estimations; (v) microscopical analysis of urine deposit; and (vi) urine culture. Microangiopathic haemolytic anaemia was excluded by appropriate blood tests. Clinical examination and chest $\mathrm{X}$ ray excluded cardiac failure. BP was measured by mercury sphygmomanometer, taking the fifth Korotkov sound as the end-point for DBP. After discharge from hospital the patient was reviewed at 2 or 3 month intervals.

During the first week of treatment GFR and ERPF were measured using ${ }^{51} \mathrm{Cr} /$ EDTA and ${ }^{123}$ //Hippuran, respectively, with a single-shot technique (Morgan et $\widetilde{N}$ al., 1977). Sequential measurements were performed over a 5-year period.

\section{Results}

Clinical details, with mean levels of SBP and DBP before and at yearly intervals after commencing antihypertensive drug treatment, are given in Table 1. 
TABLE 1. Mean SBP and DBP throughout 5 years of anti-hypertensive drug treatment

\begin{tabular}{|c|c|c|c|c|c|c|c|c|}
\hline \multirow[b]{3}{*}{ Case } & \multirow[b]{3}{*}{ Sex/age } & \multicolumn{6}{|c|}{ Blood pressure (erect position) } & \multirow{3}{*}{$\begin{array}{l}\text { Drug } \\
\text { treatment } \\
\text { regime }\end{array}$} \\
\hline & & \multirow[b]{2}{*}{$\begin{array}{l}\text { Pre-treatment } \\
(\mathrm{mmHg})\end{array}$} & \multicolumn{5}{|c|}{$\begin{array}{l}\text { Post-treatment (mean) } \\
\text { (mmHg) }\end{array}$} & \\
\hline & & & 1 & 2 & $\begin{array}{l}\text { Year } \\
3\end{array}$ & 4 & 5 & \\
\hline 1 & $\mathrm{~F} / 35$ & $\begin{array}{l}\text { SBP } 228 \\
\text { DBP } 158\end{array}$ & $\begin{array}{r}134 \\
90\end{array}$ & $\begin{array}{r}128 \\
87\end{array}$ & $\begin{array}{r}130 \\
85\end{array}$ & $\begin{array}{r}110 \\
80\end{array}$ & $\begin{array}{r}110 \\
80\end{array}$ & Labetalol, $2400 \mathrm{mg} /$ day \\
\hline 2 & $M / 49$ & $\begin{array}{l}\text { SBP } 220 \\
\text { DBP } 140\end{array}$ & $\begin{array}{l}150 \\
110\end{array}$ & $\begin{array}{l}150 \\
100\end{array}$ & $\begin{array}{r}155 \\
97\end{array}$ & $\begin{array}{c}147 \cdot 5 \\
90\end{array}$ & $\begin{array}{r}120 \\
80\end{array}$ & $\begin{array}{l}\text { Metoprolol, } 400 \mathrm{mg} \\
\text { Prazosin, } 0.5 \mathrm{mg} \text { tds } \\
\text { Bendrofluazide, } 5 \mathrm{mg} \\
\text { Minoxidil, } 10 \mathrm{mg} \text { bd } \\
\text { (substituted for prazosin } \\
\text { in year 3) }\end{array}$ \\
\hline 3 & $M / 53$ & $\begin{array}{l}\text { SBP } 260 \\
\text { DBP } 186\end{array}$ & $\begin{array}{r}160 \\
92\end{array}$ & $\begin{array}{r}155 \\
93\end{array}$ & $\begin{array}{r}160 \\
90\end{array}$ & $\begin{array}{l}166 \cdot 6 \\
90\end{array}$ & $\begin{array}{r}145 \\
85\end{array}$ & $\begin{array}{l}\text { Methyldopa, } 500 \mathrm{mg} \text { tds } \\
\text { Labetalol, } 400 \mathrm{mg} \text { tds } \\
\quad+200 \mathrm{mg} \text { nocte } \\
\text { Bumetanide mane }\end{array}$ \\
\hline 4 & $F / 62$ & $\begin{array}{l}\text { SBP } 290 \\
\text { DBP } 190\end{array}$ & $\begin{array}{r}163 \\
90\end{array}$ & $\begin{array}{r}148 \\
85\end{array}$ & $\begin{array}{r}140 \\
85\end{array}$ & $\begin{array}{r}140 \\
80\end{array}$ & $\begin{array}{r}150 \\
90\end{array}$ & $\begin{array}{l}\text { Atenolol, } 200 \mathrm{mg} / \text { day } \\
\text { Apresoline, } 75 \mathrm{mg} / \text { day } \\
\text { Hydrochlorothiazide } \\
\quad+\text { amiloride } \\
\text { In year } 3 \text { prazosin } 1 \mathrm{mg} \text { bd } \\
\text { was substituted for } \\
\text { apresoline }\end{array}$ \\
\hline
\end{tabular}

Hypertensive retinopathy regressed and completely disappeared within 2 months of starting treatment.

Serial GFR and ERPF throughout 5 years of treatment are displayed in Figs. 1 and 2, respectively.

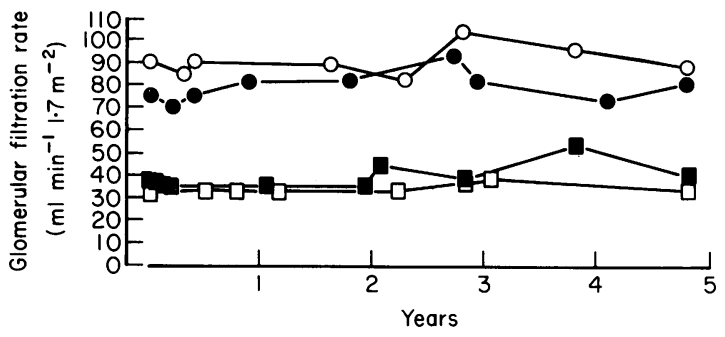

FIG. 1. GFR remained relatively constant during 5 years of adequate blood pressure control. Case: $(O) 1 ;(O) 2 ;(\square) 3 ;(\square) 4$.

\section{Discussion}

Serial GFR and ERPF determinations remained essentially unchanged throughout 5 years of effective anti-hypertensive drug treatment, presumably because of permanent structural damage to the renal vessels. In MHT these vascular changes may be related to (i) preceding vascular damage from chronic, severe, but benign hypertension (Reubi et al., 1978), or (ii) superimposed fibrinoid necrosis associated with MHT, which results from gross

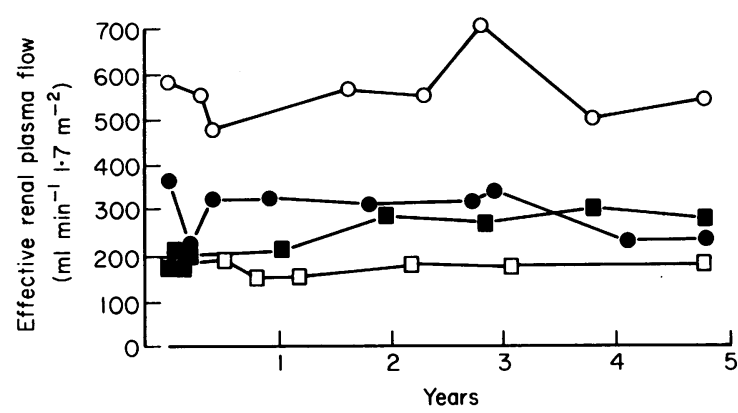

FIG. 2. ERPF remained relatively constant during hypotensive therapy. Case: $(O) 1 ;(O) 2 ;(\square) 3 ;(\square) 4$.

elevation of arterial BP or to accompanying humoral factors (Beilin and Goldby, 1977). Marked variation in the degree of initial reduction in GFR or ERPF in the present small series is consistent with a patchy distribution of fibrinoid necrosis within the arterioles. In cases 1 and 2 GFR was only mildly reduced, whereas in cases 3 and 4 there was more marked reduction.

The nature of these vascular changes, and their response to hypotensive therapy is open to speculation. The relatively constant GFR and ERPF, observed in all patients throughout treatment, contrasted with a gradual decline in SBP and DBP noted in each successive year of treatment, suggesting a poor relationship between these variables. It is 
therefore difficult to define an optimal level of SBP or DBP at which GFR or ERPF will be stabilized or improved. For example, minoxidil improved BP control in case 2 , when used in years 4 and 5 , but this did not effect an improvement in ERPF which remained low. Probably the marked reduction in GFR and ERPF observed in cases 3 and 4 reflected widespread obliterative arteriolar disease, but the data cannot distinguish vascular changes accompanying benign hypertension from MHT.

A dramatic fall in serum creatinine concentration has been observed in some patients with MHT admitted with severe impairment of renal function, who were treated with the vasodilator minoxidil (Mitchell, Graham and Pettinger, 1980; McKay et al., 1981; Taverner et al., 1983). This suggests that in those patients it is possible to reverse the vascular component due to fibrinoid necrosis. Fibrinoid necrosis may cause several types of reno-vascular damage: Type I signifies a breach of endothelium permitting entry of plasma into the media; Type II results from internal deposition of fibrin and macrophages; and Type III represents a healing phase in which endothelial restoration is coordinated by smooth muscle cell repair action (Goldby and Beilin, 1974). The untreated patient with MHT may exhibit all three types. Careful pathological study of the renal vasculature in two patients with MHT, who died suddenly from acute cardiac failure before the development of renal failure, revealed widespread obliterative disease of the renal arterioles. Successive episodes of obliterative vascular disease had affected fresh groups of arterioles over a period of time, causing a variety of acute, healing and healed vascular lesions (Sanerkin, 1977). Hypertensive retinopathy, however, regressed completely over the first two months of treatment in the current series, indicating recovery of the retinal vessels during this time interval.

In conclusion, the present series of patients with MHT demonstrated little change in GFR and ERPF throughout adequate long-term control of BP. In cases 1 and 2 the initial reduction of GFR and ERPF was mild, and hypertensive drug treatment would not $\stackrel{\AA}{\complement}$ be expected to improve these variables to any great $c$ extent. Cases 3 and 4, with more severe reduction in $\overrightarrow{\vec{F}}$ GFR and ERPF may conceivably have had longstanding benign hypertension that could have produced persisting reno-vascular damage. But it is also possible that these patients could have had obliterative fibrinoid necrosis which did not respond to antihypertensive therapy. It should be recognized that is not all patients with renal impairment due to MHT $\vec{\circ}$ recover function following adequate treatment.

\section{References}

BEILIN, L.J \& GOL humoral factors in the pathogenesis of the vascular lesions of malignant hypertension. Clinical Science and Molecular Medicine, 52, 111 .

GolDBY, F.S. \& BEILIN, L.J. (1974) The evolution and healing of arteriolar damage in renal-clip hypertension in the rat. An electron microscope study. Journal of Pathology, 114, 139.

Herlitz, H. Gudbrandsson, T. \& Hansson, L. (1982) Renal 을 function as an indicator of prognosis in malignant essential hypertension. Scandinavian Journal of Urology and Nephrology, $16,51$.

McKay, A., Isles, C., Henderson, I., Fife, R. \& Kennedy, A.C. O을 (1981) Minoxidil in the management of untractible hypertension. $\mathbb{D}$ Quarterly Journal of Medicine, 50, 175.

Mitchell, H.C., Graham, R.M. \& Pettinger, W.A. (1980) Ren? function during long-term treatment of hypertension with mino dil. Annals of Internal Medicine, 93, 676.

MORGAN, W.D., BIRKS, J.L., SIVYER, A. \& GHOSE, R.R. (1977) A표 efficient technique for the simultaneous estimation of GFR and ERPF, involving a single injection and two blood samples. International Journal of Nuclear Medicine and Biology, 4, 79.

Reubi, F.C., WeidmanN, P., Hodler, J. \& Cottier, P.T. (1978) Changes in renal function in essential hypertension. American $\propto$ Journal of Medicine, 60, 773.

SANERKIN, N.C. (1977) Vascular lesions of malignant essential hypertension. Journal of Pathology, 103, 177.

Taverner, D., Bing, R.F., Heagerty, A., Russel, G.I., Pohl, J.E.F., SWALES, J.D. \& THURSTON, H. (1983) Improvement of renal function during long-term treatment of severe hypertension with minoxidil. Quarterly Journal of Medicine, 206, 280.

(Accepted 17 April 1984) 